\title{
Human H7N9 virus induces a more pronounced pro-inflammatory cytokine but an attenuated interferon response in human bronchial epithelial cells when compared with an epidemiologically-linked chicken H7N9 virus
}

Kelvin K. W. To ${ }^{1,2,3,4 \dagger}$, Candy C. Y. Lau ${ }^{1 \dagger}$, Patrick C. Y. Woo 1,2,3,4, Susanna K. P. Lau',2,3,4, Jasper F. W. Chan 1,2,3,4, Kwok-Hung Chan ${ }^{1,2,3,4}$, Anna J. X. Zhang ${ }^{1,2,3,4}$, Honglin Chen 1,2,3,4,5 and Kwok-Yung Yuen 1,2,3,4,5*

\begin{abstract}
Background: Avian influenza virus H7N9 has jumped species barrier, causing sporadic human infections since 2013. We have previously isolated an H7N9 virus from a patient, and an H7N9 virus from a chicken in a live poultry market where the patient visited during the incubation period. These two viruses were genetically highly similar. This study sought to use a human bronchial epithelial cell line model to infer the virulence of these H7N9 viruses in humans.

Methods: Human bronchial epithelial cell line Calu-3 was infected with two H7N9 viruses (human H7N9-HU and chicken H7N9-CK), a human H5N1 virus and a human 2009 pandemic H1N1 virus. The infected cell lysate was collected at different time points post-infection for the determination of the levels of pro-inflammatory cytokines (tumor necrosis factor a [TNF-a] and interleukin 6 [IL-6]), anti-inflammatory cytokines (interleukin 10 [IL-10] and transforming growth factor beta [TGF- $\beta]$ ), chemokines (interleukin 8 [IL-8] and monocyte chemoattractant protein 1 $[\mathrm{MCP}-1]$ ), and interferons (interferon $\beta$ [IFN- $\beta]$ and interferon lambda 1 [IFNL1]). The viral load in the cell lysate was also measured.
\end{abstract}

Results: Comparison of the human and chicken H7N9 viruses showed that H7N9-HU induced significantly higher levels of TNF-a at $12 \mathrm{~h}$ post-infection, and significantly higher levels of IL-8 from 12 to $48 \mathrm{~h}$ post-infection than those of H7N9-CK. However, the level of IFNL1 was lower for H7N9-HU than that of H7N9-CK at $48 \mathrm{~h}$ post-infection $(P<0.001)$. H7N9-HU had significantly higher viral loads than H7N9-CK at 3 and $6 \mathrm{~h}$ post-infection. H5N1 induced significantly higher levels of TNF- $a, \mathrm{IL}-6, \mathrm{IL}-8, \mathrm{LL}-10$ and MCP-1 than those of H7N9 viruses at $48 \mathrm{~h}$ post-infection. Conversely, H1N1 induced lower levels of TNF- $a$, IL-10, MCP-1, IFNL1 and IFN- $\beta$ when compared with H7N9 viruses at the same time point.

(Continued on next page)

\footnotetext{
* Correspondence: kyyuen@hku.hk

${ }^{\dagger}$ Equal contributors

'Department of Microbiology, The University of Hong Kong, Hong Kong Special Administrative Region, China

${ }^{2}$ State Key Laboratory for Emerging Infectious Diseases, The University of

Hong Kong, Hong Kong Special Administrative Region, China

Full list of author information is available at the end of the article
} 
(Continued from previous page)

Conclusions: H7N9-HU induced higher levels of pro-inflammatory IL-6 and IL-8 and exhibited a more rapid viral replication than H7N9-CK. However, the level of antiviral IFNL1 was lower for H7N9-HU than H7N9-CK. Our results suggest that the gained properties in modulating human innate immunity by H7N9-HU transformed it to be a more virulent virus in humans than H7N9-CK.

Keywords: Avian influenza virus, H7N9, Human, Chicken, Cytokine, Chemokine, Interferon, Viral load, Interferon lambda 1, IL-8

\section{Background}

The avian influenza H7N9 virus has crossed species barrier, with the first cluster of human infections identified in early 2013 [1-3]. Subsequently, it has spread rapidly across the mainland China, and travel-related cases were identified in Hong Kong, Taiwan, Malaysia and Canada [4-7]. H7N9 virus is the most rapidly spreading zoonotic influenza virus affecting humans, with at least 680 cases in less than 3 years since first identified in humans [8].

H7N9 infection is a highly fatal disease in humans. The case-fatality rate of $\mathrm{H} 7 \mathrm{~N} 9$ infection in humans is about $40 \%$ [9], which is much higher than that of the 2009 pandemic H1N1 infection [10], but lower than that for $\mathrm{H} 5 \mathrm{~N} 1$ infection [11]. Unlike most patients with seasonal or pandemic influenza virus infection which present with self-limiting acute upper respiratory illness, the majority of patients with laboratory-confirmed H7N9 infections present with rapidly progressive community-acquired pneumonia, leukopenia, lymphopenia, thrombocytopenia, impaired coagulation profile, deranged liver and renal function, and some patients succumbed with adult respiratory distress syndrome and multiorgan dysfunction [12-15]. These differences in clinical severity and pathology among H7N9, H5N1 and H1N1 may be related to the differential ability of the viruses to induce cytokine and chemokine response. Cytokine and chemokine dysregulation is a hallmark in patients suffering from severe influenza [16-18]. Patients with H7N9 virus infection also had poorer antibody response when compared with those of H5N1 and $\mathrm{H} 1 \mathrm{~N} 1$ viruses [19]. The suboptimal humoral response induced by H7N9 virus may be related to their internal genes [20].

Epidemiological and phylogenetic analysis suggested that H7N9 virus is primarily transmitted from poultries to humans in live poultry markets (LPM) [2, 21-23]. In our previous study, we have isolated an $\mathrm{H} 7 \mathrm{~N} 9$ virus from a patient (A/Zhejiang/DTID-ZJU01/2013[H7N9]) (H7N9-HU) and an H7N9 virus from a chicken in an epidemiologicallylinked LPM (A/chicken/Zhejiang/DTID-ZJU01/2013[H7 N9]) (H7N9-CK) [2]. H7N9-HU and H7N9-CK had high nucleotide similarity. In a subsequent study, we have shown that H7N9-CK could cause lethal infection in mice without prior adaptation, and was associated with high pulmonary levels of pro-inflammatory cytokines [24]. In this study, we used a human bronchial epithelial cell line model to infer the virulence of the human and chicken H7N9 viruses in humans.

\section{Methods}

\section{Cell and virus isolates}

H7N9-HU was isolated from a 64-year-old male patient from Zhejiang who bought live poultry from a LPM within the incubation period, and H7N9-CK was isolated from a chicken from the LPM where that patient bought the live poultry [2]. A/Hong Kong/415742/2009(H1N1) (H1N1) and A/Vietnam/1194/2004(H5N1) (H5N1) were isolated from infected patients $[25,26]$. The viruses were propagated in 10-day-old specific-pathogen-free (SPF) chicken embryos at $37{ }^{\circ} \mathrm{C}$ for $48 \mathrm{~h}$ as we described previously [27]. Aliquots of virus stock were stored at $-80{ }^{\circ} \mathrm{C}$ until use. Calu-3 cell line (ATCC no. HTB-55) was used for the infection experiments. All experimental protocols followed the standard operating procedures of the approved biosafety level 3 facility as we previously described [25, 26, 28].

\section{Viral inoculation into Calu-3 cells}

Calu-3 cells were seeded onto 96-well tissue culture plates, at $2.5 \times 10^{4}$ cells per well with Dulbecco's Modified Eagle Medium (DMEM) supplemented with $20 \%$ fetal calf serum (FCS), $100 \mathrm{IU} / \mathrm{ml}$ of penicillin, and $100 \mu \mathrm{g} / \mathrm{ml}$ of streptomycin. The culture plates were incubated at $37{ }^{\circ} \mathrm{C}$ and $5 \% \mathrm{CO}_{2}$ for $48 \mathrm{~h}$ prior to the experiment. Cells were inoculated with 3 multiplicity of infection (M.O.I.) of each virus. After $1 \mathrm{~h}$ of viral adsorption, the medium was removed and cells were washed twice with medium before further incubation for 3, 6, 12, 24 and $48 \mathrm{~h}$ in DMEM containing tosylsulfonyl phenylalanylchloromethyl ketone (TPCK)-treated trypsin $(0.5 \mu \mathrm{g} / \mathrm{ml})$ (Sigma). Cell lysates were collected for cytokine and viral load assays. The experiments were performed in triplicate.

Determination of the levels of cytokines and chemokines The levels of cytokines and chemokines were determined by real-time reverse transcription-quantitative polymerase chain reaction (RT-qPCR) as we described previously [25]. RNA extraction was performed using 
RNeasy Mini Spin Column (QIAgen). The RNA was eluted in $50 \mu \mathrm{l}$ of RNase-free water and was used as the template for RT-qPCR. Reverse transcription was performed using the oligo(dt) primer with the SuperScript III kit (Invitrogen). RT-qPCR assays for tumor necrosis factor $\alpha$ (TNF- $\alpha$ ), interleukin 6 (IL-6), interleukin 8 (IL-8), interleukin 10 (IL-10), transforming growth factor beta (TGF- $\beta$ ), interferon lambda 1 (IFNL1), interferon $\beta$ (IFN- $\beta$ ), and monocyte chemoattractant protein 1 (MCP-1) were performed as described previously with primers and conditions listed in Table 1, using glyceraldehyde 3-phosphate dehydrogenase (GAPDH) for normalization [25]. cDNA was amplified in a LightCycler 2.0 (Roche) with $20 \mu \mathrm{l}$ reaction mixtures containing FastStart DNA Master SYBR Green I Mix reagent kit (Roche), $2 \mu \mathrm{l} \mathrm{cDNA}, 2$ or $4 \mathrm{mM} \mathrm{MgCl}_{2}$ and $1 \mu \mathrm{M}$ primers at $95^{\circ} \mathrm{C}$ for $10 \mathrm{~min}$ followed by 50 cycles of denaturation, annealing and extension. Melting curve analysis was performed for each primer pair at the end of the reaction to confirm the specificity of the assay.

\section{Viral load}

To study viral replication kinetics, viral titer from cell lysates collected at $3,6,12,24$ and $48 \mathrm{~h}$ post-infection were measured by RT-qPCR as described previously [25].

\section{Statistical analysis}

Statistical analysis was performed using GraphPad Prism 6.0. The levels of cytokines and chemokines were expressed as fold-increase from mock-infected cells. The cytokine/chemokine levels and viral loads of different viruses were compared using Student's t-test when comparing between two viruses, and two-way ANOVA test corrected for multiple comparisons using Tukey posthoc test when comparing 3 different viruses. A $P$ value of $<0.05$ was considered statistically significant.

\section{Results}

We compared the cytokine and chemokine levels between the human and chicken H7N9 viruses in a human bronchial epithelial cell line Calu-3. At $12 \mathrm{~h}$ postinfection, the mean level of TNF- $\alpha$ was significantly higher for H7N9-HU (220-fold) than that of H7N9-CK (55-fold) $(P=0.010)$. The mean level of TNF- $\alpha$ at $24 \mathrm{~h}$ post-infection was also higher for H7N9-HU (458-fold) than that of H7N9-CK (224-fold), almost reaching statistical significance $(P=0.068)$. However, at $48 \mathrm{~h}$ postinfection, the mean level of TNF- $\alpha$ was similar between H7N9-HU (289-fold) and H7N9-CK (307-fold) $(P=0.802)$. H7N9-HU also induced significantly higher levels of IL-8 from 12-48 h post-infection than those of H7N9-CK. Conversely, the mean level of IFNL1 was significantly lower for H7N9-HU (39fold) than that of H7N9-CK (55-fold) at $48 \mathrm{~h}$ postinfection $(P=0.0005)$. The mean level of MCP-1 was also significantly lower for H7N9-HU than H7N9-CK at $48 \mathrm{~h}$ post-infection $(P=0.014)$. There was no significant difference for other cytokines/chemokines.

Next, we compared the H7N9 viruses with the more virulent $\mathrm{H} 5 \mathrm{~N} 1$ and the less virulent $\mathrm{H} 1 \mathrm{~N} 1$ viruses. When compared with H7N9-CK or H7N9-HU, H5N1 induced significantly higher levels of IL- 8 at $12 \mathrm{~h}$ post-infection; IL-8, IL-6, IL-10 and MCP-1 at 24 h post-infection; and IL-8, IL-6, IL-10, MCP-1 and TNF- $\alpha$ at $48 \mathrm{~h}$ postinfection (Fig. 1). Unlike H5N1, H1N1 induced significantly lower levels of IL-6, MCP- 1 and TNF- $\alpha$ at $24 \mathrm{~h}$ post-infection; and MCP-1, TNF- $\alpha$, IL-10, IFNL1 and IFN- $\beta$ at $48 \mathrm{~h}$ post-infection when compared with H7N9-CK or H7N9-HU.

The viral kinetics were also determined (Fig. 2). At 3 and $6 \mathrm{~h}$ post infection, the viral load achieved by H7N9-CK were about $1 \log$ lower than that of H7N9-HU $(P<0.005)$. At $48 \mathrm{~h}$ post-infection, the viral load of H7N9-CK was significantly higher than those of H7N9-HU $(P<0.001)$.

Table 1 Primers and conditions for real-time RT-PCR

\begin{tabular}{|c|c|c|c|c|c|c|}
\hline \multirow[t]{2}{*}{ Cytokines } & \multicolumn{6}{|l|}{ Primers } \\
\hline & Forward & Backward & $\begin{array}{l}\text { Mg conc. } \\
(\mathrm{mM})\end{array}$ & Denaturation & Annealing & Extension \\
\hline TNF-a & GCCAGAGGGCTGATTAGAGA & CAGCCTCTTCTCCTTCCTGAT & 2 & $95^{\circ} \mathrm{C} 10 \mathrm{~s}$ & $60^{\circ} \mathrm{C} 5 \mathrm{~s}$ & $72{ }^{\circ} \mathrm{C} 5 \mathrm{~s}$ \\
\hline MCP-1 & GCAATCAATGCCCCAGTCA & TGCTGCTGGTGATTCTTCTATAGCT & 2 & $95^{\circ} \mathrm{C} 10 \mathrm{~s}$ & $55^{\circ} \mathrm{C} 5 \mathrm{~s}$ & $72{ }^{\circ} \mathrm{C} 5 \mathrm{~s}$ \\
\hline IL-6 & GGTACATCCTCGACGGCATCT & GTGCCTCTTTGCTGCTITCAC & 2 & $95^{\circ} \mathrm{C} 10 \mathrm{~s}$ & $55^{\circ} \mathrm{C} 5 \mathrm{~s}$ & $72{ }^{\circ} \mathrm{C} 5 \mathrm{~s}$ \\
\hline IFN- $\beta$ & GCCGCATTGACCATCT & CACAGTGACTGTACTCCT & 4 & $95^{\circ} \mathrm{C} 10 \mathrm{~s}$ & $55^{\circ} \mathrm{C} 5 \mathrm{~s}$ & $72{ }^{\circ} \mathrm{C} 11 \mathrm{~s}$ \\
\hline IFNL1 & GAAGCAGTTGCGATTTAGCC & GAAGCTCGCTAGCTCCTGTG & 2 & $95^{\circ} \mathrm{C} 10 \mathrm{~s}$ & $60^{\circ} \mathrm{C} 5 \mathrm{~s}$ & $72{ }^{\circ} \mathrm{C} 7 \mathrm{~s}$ \\
\hline $\mathbb{I L}-10$ & CAAATGAAGGATCAGCTGGACAA & GCATCACCTCCTCCAGGTAAAAC & 2 & $95^{\circ} \mathrm{C} 10 \mathrm{~s}$ & $55^{\circ} \mathrm{C} 5 \mathrm{~s}$ & $72{ }^{\circ} \mathrm{C} 5 \mathrm{~s}$ \\
\hline TGF- $\beta$ & CCCAGCATCTGCAAAGCTC & GTCAATGTACAGCTGCCGCA & 2 & $95^{\circ} \mathrm{C} 10 \mathrm{~s}$ & $55^{\circ} \mathrm{C} 5 \mathrm{~s}$ & $72{ }^{\circ} \mathrm{C} 5 \mathrm{~s}$ \\
\hline IL-8 & AGCTGGCCGTGGCTCTCT & CTGACATCTAAGTTCTTTAGCACTCCTT & 2 & $95^{\circ} \mathrm{C} 10 \mathrm{~s}$ & $55^{\circ} \mathrm{C} 5 \mathrm{~s}$ & $72{ }^{\circ} \mathrm{C} 5 \mathrm{~s}$ \\
\hline GAPDH & ATTCCACCCATGGCAAATTC & CGCTCCTGGAAGATGGTGAT & 2 & $95^{\circ} \mathrm{C} 10 \mathrm{~s}$ & $55^{\circ} \mathrm{C} 5 \mathrm{~s}$ & $72{ }^{\circ} \mathrm{C} 5 \mathrm{~s}$ \\
\hline
\end{tabular}




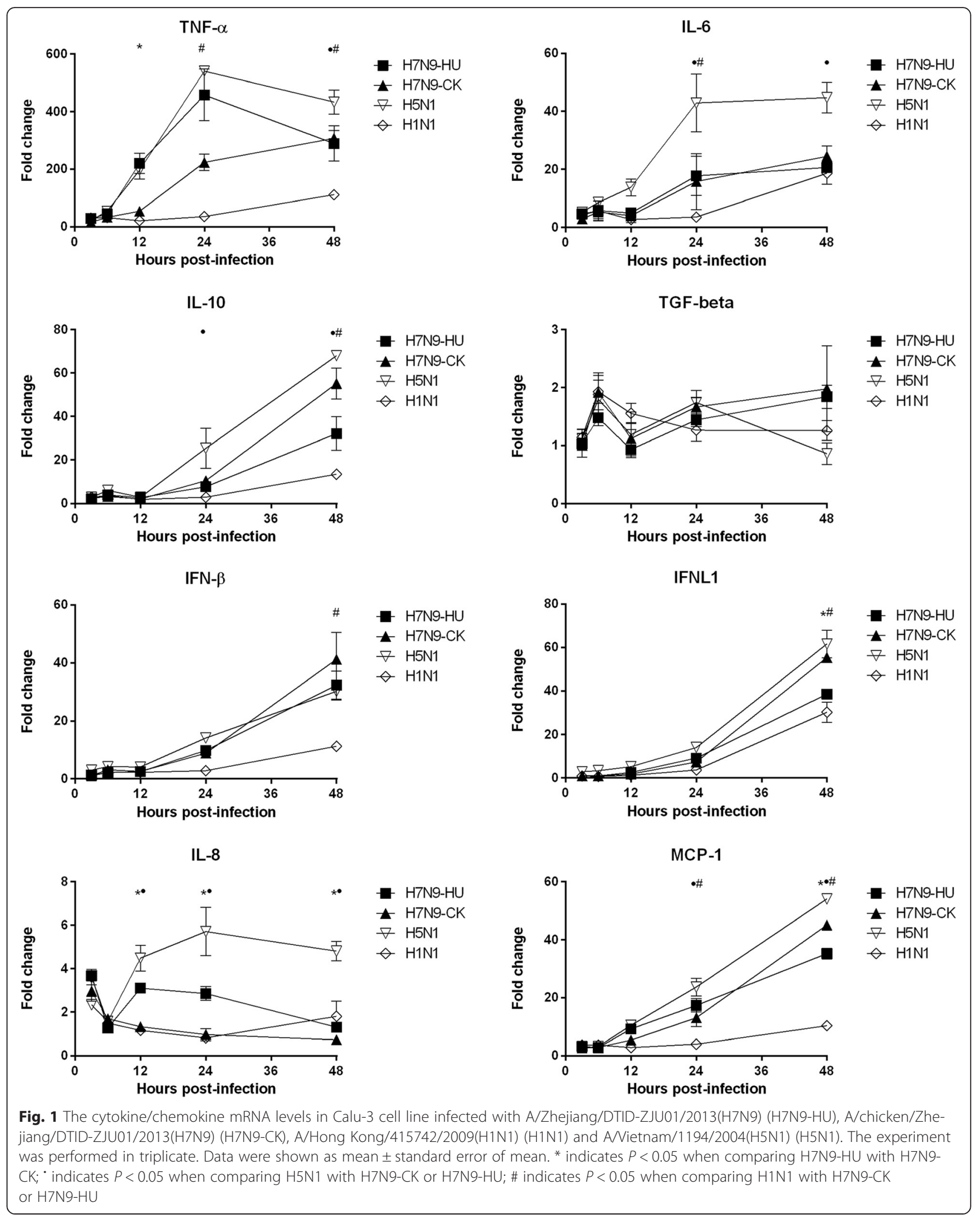




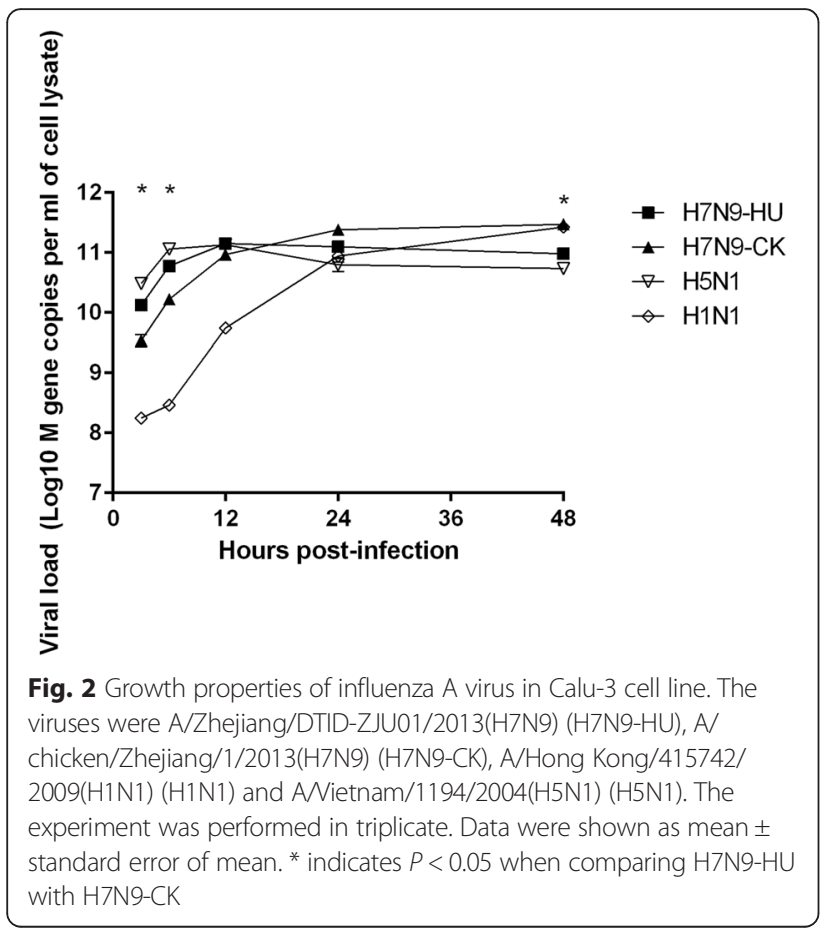

\section{Discussion}

Severe influenza is characterized by rapidly progressive pneumonia, acute respiratory distress syndrome and multiorgan failure $[11,12,14]$. An exaggerated innate immune response is observed in severe influenza cases, manifested with elevated levels of pro-inflammatory or antiinflammatory cytokines and chemokines [15-17, 29, 30]. Although some studies have compared human H7N9 viruses with poultry $\mathrm{H} 7 \mathrm{~N} 9$ viruses or with other subtypes of human or avian influenza viruses [31-35], there have not been any studies which compared the cytokine/chemokine responses and the replication of H7N9 viruses isolated from human and poultry in epidemiologically-linked markets. In the current study, we compared human and poultry H7N9 viruses that were closely related both epidemiologically and phylogenetically. When compared with the chicken H7N9-CK, the human H7N9-HU induced a stronger TNF- $\alpha$ response at 12 and $24 \mathrm{~h}$ post-infection, but a weaker IFNL1 response between 12 and $48 \mathrm{~h}$ postinfection. H7N9-HU also replicated more rapidly than H7N9-CK in the first 6 h. H7N9-HU and H7N9-CK are highly similar, with $99.4 \%$ and $99.7 \%$ nucleotide identity in their hemagglutinin and neuraminidase genes, respectively [2]. However, there are two major amino acid differences between the human and chicken H7N9 virus. H7N9-HU has a Gln226Leu substitution (H3 numbering) in the hemagglutinin, which is responsible for an increase binding affinity to the human type $\alpha$-2,6-linked sialic acid receptor. H7N9$\mathrm{HU}$ also contains an Asp701Asn substitution in PB2, which has been shown to enhance transmission in guinea pigs.

Our cytokine/chemokine findings suggest that H7N9$\mathrm{HU}$ induced a greater proinflammatory response than H7N9-CK. These results corroborate with the results of an in vivo model by Zhang et al. [35]. In their study, ferrets infected with human H7N9 strains had greater weight loss, more severe bronchopneumonia, and higher viral loads in the tonsils, trachea and lung than ferrets infected with a chicken H7N9 strain. However, the cytokine/chemokine profiles or other immune profiles of these ferrets were not reported.

We have chosen Calu-3 cell line because bronchial epithelial cell is one of the cell types affected in patients with severe influenza [36]. Calu-3 has been widely used for studies on the pathogenesis of influenza virus and other respiratory viruses [31, 37-39]. McDermott et al. showed that host response induced by high pathogenic avian influenza virus in Calu-3 correlated with that of mouse and macaque models [40].

In this study, we have shown that the level of TNF- $\alpha$ was higher in Calu-3 cells infected with H7N9-HU than that of H7N9-CK. TNF- $\alpha$ is a major pro-inflammatory cytokine. Our results corroborate with those in a study showing higher pulmonary level of TNF- $\alpha$ in mice infected with a human H7N9 virus when compared to that of mice infected with a duck H7N9 virus from 2009 [41]. The level of TNF- $\alpha$ was also increased in H7N9 patients [2], although the level of TNF- $\alpha$ was not associated with the prognosis of patients [17, 42].

The level of IL-8 was also higher for H7N9-HU than that of H7N9-CK. IL-8, or CXCL8, is a chemokine which attracts and activates neutrophils. Previous studies showed that human $\mathrm{H} 7 \mathrm{~N} 9$ and $\mathrm{H} 5 \mathrm{~N} 1$ viruses induced higher levels of IL-8 than seasonal H3N2 virus or an H7N9 virus isolated from a shoveler in 2007 [31]. In patients with 2009 pandemic H1N1 virus infection, the levels of IL-8 were also found to be higher in patients with severe disease than those with mild disease [10]. In humans, IL-8 has been associated with acute lung injury [43].

On the contrary, the levels of IFNL1 and MCP-1 were lower in Calu-3 cells infected with H7N9-HU than that of H7N9-CK at $48 \mathrm{~h}$ post-infection. IFNL1, also known as IL-29, is an antiviral type III interferon. Administration of IFNL1 can reduce the viral load in vitro [44]. In previous studies, avian influenza viruses $\mathrm{H} 5 \mathrm{~N} 2$ and H9N2 induced robust IFNL1 response in the lung alveolar epithelial A549 cells [45]. MCP-1 is a chemokine mainly responsible for recruiting monocytes. MCP-1 is required for protective response, as treatment of influenza-infected mice with MCP-1 antibody resulted in greater lung damage [46]. However, a higher level of MCP-1 was found in patients who died than those survivors at week 2 post-infection, suggesting that a 
persistently high level of MCP-1 is associated with poorer prognosis [17].

The viral titers of H7N9-HU were higher than those of H7N9-CK at 3 and $6 \mathrm{~h}$ post-infection. This is consistent with another study which showed that the viral titers of the human H7N9 viruses were higher than those of phylogenetically unrelated duck H7N9 virus and the 2009 pandemic H1N1 virus in differentiated normal human bronchial epithelial cells [47]. In another study, a human H7N9 virus was also shown to have better replication in explanted human lung tissue than lowpathogenic avian H7N1 and H7N7 isolated from turkeys [48]. The lower level of IFNL1 and a more rapid viral replication in H7N9-HU-infected cells suggest that H7N9-HU has acquired additional characteristics that enhance the virulence in humans.

Similar to other studies, we have demonstrated that the cytokine/chemokine mRNA expression levels and the viral loads of H7N9, H5N1 and H1N1 virus in Calu3 cells correlated well with disease severity observed in humans [31]. The avian influenza virus $\mathrm{H} 5 \mathrm{~N} 1$, which has a case-fatality rate about $53 \%$ [9], induced the highest mRNA expression levels of most tested cytokines/chemokines. On the other hand, the 2009 pandemic H1N1, which has a $<1 \%$ case-fatality rate [10], induced the lowest mRNA levels of cytokines/chemokines and the lowest viral load. The avian influenza virus H7N9, which has a case-fatality rate of $40 \%$ [9], induced moderate levels of cytokines/chemokines. H7N9 was also shown to induce a cytokine profile between that of $\mathrm{H} 5 \mathrm{~N} 1$ and seasonal influenza viruses in primary human macrophages and those in endothelial cells $[31,49]$.

\section{Conclusions}

In summary, while only few adaptive mutations were observed between H7N9 human and avian viruses, the results of our study suggested that $\mathrm{H} 7 \mathrm{~N} 9-\mathrm{HU}$ is more virulent in humans than H7N9-CK. The ability to induce inflammation and the kinetics of viral replication in human cells may be common parameters in predicting the virulence and replication potential of an emerging avian influenza virus in humans.

\section{Competing interests}

The authors declare that they have no competing interests.

\footnotetext{
Authors' contributions

KKWT conceived of the study, participated in its design and coordination, analyzed and interpreted the data, drafted the manuscript, and approved the final version of the manuscript. CCYL participated in the acquisition, analysis and interpretation of data, revised the manuscript critically for important intellectual content, and approved the final version of the manuscript. PCYW conceived of the study, participated in its design, analyzed and interpreted the data, revised the manuscript critically for important intellectual content, and approved the final version of the manuscript. SKPL analyzed and interpreted the data, revised the manuscript critically for important intellectual content, and approved the final version of the manuscript. JFWC analyzed and interpreted the data, revised the manuscript critically for
}

important intellectual content, and approved the final version of the manuscript. KHC participated in the acquisition, analysis and interpretation of data, revised the manuscript critically for important intellectual content, and approved the final version of the manuscript. AJXZ analyzed and interpreted the data, revised the manuscript critically for important intellectual content, and approved the final version of the manuscript. $\mathrm{HC}$ analyzed and interpreted the data, revised the manuscript critically for important intellectual content, and approved the final version of the manuscript. KYY conceived of the study, participated in its design and coordination, analyzed and interpreted the data, revised the manuscript critically for important intellectual content, and approved the final version of the manuscript.

\section{Acknowledgement}

This work was supported in part by the Providence Foundation Ltd, in memory of the late Lui Hac Minh, Cheer Master Investments Ltd (Mr Yeung Sai Hong), and a donation from Larry Chi-Kin Yung.

\section{Author details}

'Department of Microbiology, The University of Hong Kong, Hong Kong Special Administrative Region, China. ${ }^{2}$ State Key Laboratory for Emerging Infectious Diseases, The University of Hong Kong, Hong Kong Special Administrative Region, China. ${ }^{3} \mathrm{Carol}$ Yu Centre for Infection, The University of Hong Kong, Hong Kong Special Administrative Region, China. ${ }^{4}$ Research Centre of Infection and Immunology, The University of Hong Kong, Hong Kong Special Administrative Region, China. ${ }^{5}$ Collaborative Innovation Center for Diagnosis and Treatment of Infectious Diseases, Hangzhou, China.

Received: 7 January 2016 Accepted: 8 March 2016

Published online: 15 March 2016

\section{References}

1. To KK, Chan JF, Chen H, Li L, Yuen KY. The emergence of influenza A H7N9 in human beings 16 years after influenza A H5N1: a tale of two cities. Lancet Infect Dis. 2013;13:809-21.

2. Chen Y, Liang W, Yang S, Wu N, Gao H, Sheng J, Yao H, Wo J, Fang Q, Cui $D$, et al. Human infections with the emerging avian influenza $A$ H7N9 virus from wet market poultry: clinical analysis and characterisation of viral genome. Lancet. 2013;381:1916-25.

3. Gao R, Cao B, Hu Y, Feng Z, Wang D, Hu W, Chen J, Jie Z, Qiu H, Xu K, et al. Human infection with a novel avian-origin influenza A (H7N9) virus. N Engl J Med. 2013;368:1888-97.

4. To KK, Song W, Lau SY, Que TL, Lung DC, Hung IF, Chen H, Yuen KY. Unique reassortant of influenza $A(H 7 N 9)$ virus associated with severe disease emerging in Hong Kong. J Infect. 2014;69:60-8.

5. Marjuki H, Mishin VP, Chesnokov AP, Jones J, De La Cruz JA, Sleeman K, Tamura D, Nguyen HT, Wu HS, Chang FY, et al. Characterization of drugresistant influenza $A(H 7 N 9)$ variants isolated from an oseltamivir-treated patient in Taiwan. J Infect Dis. 2015;211:249-57.

6. William T, Thevarajah B, Lee SF, Suleiman M, Jeffree MS, Menon J, Saat Z, Thayan R, Tambyah PA, Yeo TW et al. Avian influenza (H7N9) virus infection in Chinese tourist in Malaysia, 2014. Emerg Infect Dis. 2015;21:142-5.

7. World Health Organization: Human infection with avian influenza A(H7N9) virus - Canada. Available at http://www.who.int/csr/don/01-february-2015avian-influenza/en/. Accessed on December 10, 2015.

8. Centre for Health Protection: Avian Influenza Report. Reporting period: December 6, 2015 - December 12, 2015 (Week 50). 2015.

9. World Health Organization: Influenza at the human-animal interface. Summary and assessment as of 14 December 2015. Available at http:// www.who.int/influenza/human_animal_interface/Influenza_Summary_IRA_ HA_interface_14_Dec_2015.pdf?ua=1. Accessed on December 23, 2015.

10. Cheng VC, To KK, Tse H, Hung IF, Yuen KY. Two years after pandemic influenza A/2009/H1N1: what have we learned? Clin Microbiol Rev. 2012;25:223-63.

11. To KK, Ng KH, Que TL, Chan JM, Tsang KY, Tsang AK, Chen H, Yuen K. Avian influenza A H5N1 virus: a continuous threat to humans. Emerg Microbes Infect. 2012;1, e25.

12. To KK, Chan JF, Yuen KY. Viral lung infections: epidemiology, virology, clinical features, and management of avian influenza A(H7N9). Curr Opin Pulm Med. 2014;20:225-32. 
13. Wang C, Yu H, Horby PW, Cao B, Wu P, Yang S, Gao H, Li H, Tsang TK, Liao $\mathrm{Q}$, et al. Comparison of patients hospitalized with influenza A subtypes H7N9, H5N1, and 2009 pandemic H1N1. Clin Infect Dis. 2014;58:1095-103.

14. Short KR, Kroeze EJ, Fouchier RA, Kuiken T. Pathogenesis of influenza-induced acute respiratory distress syndrome. Lancet Infect Dis. 2014;14:57-69.

15. Yu L, Wang Z, Chen Y, Ding W, Jia H, Chan JF, To KK, Chen H, Yang Y, Liang W et al. Clinical, virological, and histopathological manifestations of fatal human infections by avian influenza A(H7N9) virus. Clin Infect Dis. 2013;57:1449-57.

16. To KK, Hung IF, Li IW, Lee KL, Koo CK, Yan WW, Liu R, Ho KY, Chu KH, Watt $\mathrm{CL}$, et al. Delayed clearance of viral load and marked cytokine activation in severe cases of pandemic H1N1 2009 influenza virus infection. Clin Infect Dis. 2010;50:850-9.

17. Guo J, Huang F, Liu J, Chen Y, Wang W, Cao B, Zou Z, Liu S, Pan J, Bao C, et al. The Serum Profile of Hypercytokinemia Factors Identified in H7N9Infected Patients can Predict Fatal Outcomes. Sci Rep. 2015;5:10942.

18. Wang Z, Zhang A, Wan Y, Liu X, Qiu C, Xi X, Ren Y, Wang J, Dong Y, Bao $M$, et al. Early hypercytokinemia is associated with interferoninduced transmembrane protein-3 dysfunction and predictive of fatal H7N9 infection. Proc Natl Acad Sci U S A. 2014;111:769-74.

19. Guo L, Zhang X, Ren L, Yu X, Chen L, Zhou H, Gao X, Teng Z, Li J, Hu $J$, et al. Human antibody responses to avian influenza $A(H 7 N 9)$ virus, 2013. Emerg Infect Dis. 2014;20:192-200

20. Lee AC, Zhu H, Zhang AJ, Li C, Wang P, Li C, Chen H, Hung IF, To KK, Yuen KY. Suboptimal Humoral Immune Response against Influenza A(H7N9) Virus Is Related to Its Internal Genes. Clin Vaccine Immunol. 2015;22:1235-43.

21. Wu D, Zou S, Bai T, Li J, Zhao X, Yang L, Liu H, Li X, Yang X, Xin L, et al. Poultry farms as a source of avian influenza $A$ (H7N 9 ) virus reassortment and human infection. Sci Rep. 2015;5:7630

22. Cui L, Liu D, Shi W, Pan J, Qi X, Li X, Guo X, Zhou M, Li W, Li J, et al. Dynamic reassortments and genetic heterogeneity of the human-infecting influenza A (H7N9) virus. Nat Commun. 2014;5:3142.

23. Yang S, Chen Y, Cui D, Yao H, Lou J, Huo Z, Xie G, Yu F, Zheng S, Yang Y et al. Avian-origin influenza $A(H 7 N 9)$ infection in influenza $A(H 7 N 9)$-affected areas of China: a serological study. J Infect Dis. 2014;209:265-9.

24. Li C, Li C, Zhang AJ, To KK, Lee AC, Zhu H, Wu HW, Chan JF, Chen H, Hung IF, et al. Avian influenza A H7N9 virus induces severe pneumonia in mice without prior adaptation and responds to a combination of zanamivir and COX-2 inhibitor. PLoS ONE. 2014;9:e107966.

25. Woo PC, Tung ET, Chan KH, Lau CC, Lau SK, Yuen KY. Cytokine profiles induced by the novel swine-origin influenza A/H1N1 virus: implications for treatment strategies. J Infect Dis. 2010;201:346-53.

26. Li IW, Chan KH, To KW, Wong SS, Ho PL, Lau SK, Woo PC, Tsoi HW, Chan JF, Cheng VC, et al. Differential susceptibility of different cell lines to swineorigin influenza A H1N1, seasonal human influenza A H1N1, and avian influenza A H5N1 viruses. J Clin Virol. 2009:46:325-30.

27. Zhang AJ, To KK, Li C, Lau CC, Poon VK, Chan CC, Zheng BJ, Hung IF, Lam KS, XU A, Yuen KY. Leptin mediates the pathogenesis of severe 2009 pandemic influenza $A(H 1 N 1)$ infection associated with cytokine dysregulation in mice with diet-induced obesity. J Infect Dis. 2013;207:1270-80.

28. Chan JF, Chan KH, Choi GK, To KK, Tse H, Cai JP, Yeung ML, Cheng VC, Chen $\mathrm{H}$, Che XY, et al. Differential cell line susceptibility to the emerging novel human betacoronavirus 2C EMC/2012: implications for disease pathogenesis and clinical manifestation. J Infect Dis. 2013;207:1743-52

29. de Jong MD, Simmons CP, Thanh TT, Hien VM, Smith GJ, Chau TN, NV, Khanh $\mathrm{TH}$, Dong VC, et al. Fatal outcome of human influenza A (H5N1) is associated with high viral load and hypercytokinemia. Nat Med. 2006; 12:1203-7.

30. Chan JF, To KK, Tse H, Lau CC, Li IW, Hung IF, Chan KH, Cheng VC, Lai TS, Woo PC, et al. The lower serum immunoglobulin G2 level in severe cases than in mild cases of pandemic H1N1 2009 influenza is associated with cytokine dysregulation. Clin Vaccine Immunol. 2011;18:305-10.

31. Zeng H, Belser JA, Goldsmith CS, Gustin KM, Veguilla V, Katz JM, Tumpey TM: $A(H 7 N 9)$ virus results in early induction of proinflammatory cytokine responses in both human lung epithelial and endothelial cells and shows increased human adaptation compared with avian H5N1 virus. J Virol. 2015;89:4655-67.

32. Chan MC, Chan RW, Chan LL, Mok CK, Hui KP, Fong JH, Tao KP, Poon LL, Nicholls JM, Guan Y, Peiris JS: Tropism and innate host responses of a novel avian influenza A H7N9 virus: an analysis of ex-vivo and in-vitro cultures of the human respiratory tract. Lancet Respir Med. 2013;1:534-42.
33. Morrison J, Josset L, Tchitchek N, Chang J, Belser JA, Swayne DE, PantinJackwood MJ, Tumpey TM, Katze MG: H7N9 and other pathogenic avian influenza viruses elicit a three-pronged transcriptomic signature that is reminiscent of 1918 influenza virus and is associated with lethal outcome in mice. J Virol. 2014;88:10556-68.

34. Josset L, Zeng H, Kelly SM, Tumpey TM, Katze MG. Transcriptomic characterization of the novel avian-origin influenza A (H7N9) virus: specific host response and responses intermediate between avian (H5N1 and H7N7) and human ( $\mathrm{H} 3 \mathrm{~N} 2)$ viruses and implications for treatment options. MBio. 2014;5:e01102-13.

35. Zhang Q, Shi J, Deng G, Guo J, Zeng X, He X, Kong H, Gu C, Li X, Liu J, et al. H7N9 influenza viruses are transmissible in ferrets by respiratory droplet. Science. 2013;341:410-4.

36. Davis AS, Chertow DS, Moyer JE, Suzich J, Sandouk A, Dorward DW, Logun C, Shelhamer JH, Taubenberger JK: Validation of normal human bronchial epithelial cells as a model for influenza A infections in human distal trachea. J Histochem Cytochem. 2015;63:312-28.

37. Pearce MB, Jayaraman A, Pappas C, Belser JA, Zeng H, Gustin KM, Maines TR, Sun X, Raman R, Cox NJ, et al. Pathogenesis and transmission of swine origin A(H3N2)v influenza viruses in ferrets. Proc Natl Acad Sci U S A. 2012; 109:3944-9.

38. Aevermann BD, Pickett BE, Kumar S, Klem EB, Agnihothram S, Askovich PS, Bankhead A, 3rd, Bolles M, Carter V, Chang J, et al. A comprehensive collection of systems biology data characterizing the host response to viral infection. Sci Data. 2014;1:140033.

39. Lau SK, Lau CC, Chan KH, Li CP, Chen H, Jin DY, Chan JF, Woo PC, Yuen KY: Delayed induction of proinflammatory cytokines and suppression of innate antiviral response by the novel Middle East respiratory syndrome coronavirus: implications for pathogenesis and treatment. J Gen Virol. 2013; 94:2679-90.

40. McDermott JE, Shankaran H, Eisfeld AJ, Belisle SE, Neuman G, Li C, McWeeney S, Sabourin C, Kawaoka Y, Katze MG, Waters KM: Conserved host response to highly pathogenic avian influenza virus infection in human cell culture, mouse and macaque model systems. BMC Syst Biol. 2011;5:190.

41. Mok CK, Lee HH, Chan MC, Sia SF, Lestra M, Nicholls JM, Zhu H, Guan $Y$, Peiris JM: Pathogenicity of the novel A/H7N9 influenza virus in mice. MBio. 2013:4.

42. Chi Y, Zhu Y, Wen T, Cui L, Ge Y, Jiao Y, Wu T, Ge A, Ji H, Xu K, et al. Cytokine and chemokine levels in patients infected with the novel avian influenza A (H7N9) virus in China. J Infect Dis. 2013;208:1962-7.

43. Allen TC, Kurdowska A. Interleukin 8 and acute lung injury. Arch Pathol Lab Med. 2014;138:266-9.

44. Wang J, Oberley-Deegan R, Wang S, Nikrad M, Funk CJ, Hartshorn KL, Mason RJ: Differentiated human alveolar type II cells secrete antiviral IL29 (IFN-lambda 1) in response to influenza A infection. J Immunol. 2009:182:1296-304.

45. Sutejo R, Yeo DS, Myaing MZ, Hui C, Xia J, Ko D, Cheung PC, Tan BH, Sugrue RJ: Activation of type I and III interferon signalling pathways occurs in lung epithelial cells infected with low pathogenic avian influenza viruses. PLoS ONE. 2012;7:e33732.

46. Narasaraju T, Ng HH, Phoon MC, Chow VT. MCP-1 antibody treatment enhances damage and impedes repair of the alveolar epithelium in influenza pneumonitis. Am J Respir Cell Mol Biol. 2010;42:732-43.

47. Watanabe T, Kiso M, Fukuyama S, Nakajima N, Imai M, Yamada S, Murakami S, Yamayoshi S, Iwatsuki-Horimoto K, Sakoda Y, et al. Characterization of H7N9 influenza A viruses isolated from humans. Nature. 2013;501:551-5.

48. Knepper J, Schierhorn KL, Becher A, Budt M, Tonnies M, Bauer T, Schneider P, Neudecker J, Ruckert JC, Gruber AD, et al. The novel human influenza $\mathrm{A}(\mathrm{H} 7 \mathrm{~N} 9)$ virus is naturally adapted to efficient growth in human lung tissue. MBio. 2013;4:e00601-13.

49. Zhao C, Qi X, Ding M, Sun X, Zhou Z, Zhang S, Zen K, Li X: Proinflammatory cytokine dysregulation is associated with novel avian influenza A (H7N9) virus in primary human macrophages. J Gen Virol. 2015. 